abp Edward Ozorowski

Archidiecezjalne Wyższe Seminarium Duchowne w Białymstoku

DOI: $10.15290 / \mathrm{std} .2017 .03 .10$

\title{
WIDZIALNOŚĆ DZIEŁA ZBAWIENIA W INTERPRETACJI ŚW. AMBROŻEGO I ŚW. LEONA WIELKIEGO
}

\section{THE VISIBILITY OF WORK OF SALVATION ACCORDING TO SAINT AMBROSE AND SAINT LEO THE GREAT}

The author takes the problem of visibility of God in the world, especially after coming of Jesus Christ. Very important to him is the sentence of Saint Leo the Great: all what was visible in Christ transformed in holy sacraments. So, for all people, who participate in the Christian liturgy is more necessary to see, what is unseen; than to see what is seen. Reality unseen lasts; all what is seen - passes. .

Key words: salvation, visibility of salvation, liturgy, sacraments, Fathers of the Church.

Każdy człowiek nosi w sobie pragnienie widzenia. Dobry wzrok napawa człowieka radością, a ślepota czyni go smutnym. Pragnienie widzenia prowadzi często człowieka poza obręb zwykłego wzroku, co sprawia, iż wynajduje różnorakie narzędzia doskonalące oko (okulary, lunety, teleskopy itp.). Pragnienie to nie zatrzymuje się na granicach wszechświata i stara się wznosić coraz wyżej i schodzić coraz głębiej w rzeczywistość, która - o dziwo - nie daje mu się poznać do końca. Problem ten towarzyszył ludziom od początku, a dziś nieraz sprawia wiele kłopotu i to takiego, który pozostawia człowieka w błędzie. Staje się on tragiczny, gdy niweczy osiągnięcie celu ostatecznego. Stąd poszukiwanie 
rozwiązania tego problemu wydaje się konieczne. O pomoc sięgnęliśmy do św. Ambrożego i św. Leona.

\section{Widzialność w ideologii postmodernistycznej}

Widzeniu oczu towarzyszy zwykle wzrok intelektu. Gdy jest on sprawny, uruchamia rozumowanie. Może ono weryfikować rzeczywistość samą w sobie lub wnioski wyciągane w jego toku. Pierwszą drogą poszły nauki przyrodnicze, drugą - nauki filozoficzne. W jednym i drugim przypadku dochodzi do głosu oczywistość (evidentia). Weryfikuje ona dane widzenia zmysłowego i wyciągane z niego wnioski. W pierwszym obszarze prym wiodła techne - ars, w drugim aletheia - scientia. Kultura europejska przez wiele wieków rozwijała myślenie filozoficzne, pozostawiając w cieniu badania techniczne. Z czasem jednak głównie w XIV wieku, filozofia stała się zbyt wyrafinowana i zwrócono się ku naukom humanistycznym. Zwrot ten rozpoczął Erazm z Rotterdamu. Chociaż zawęził on przedmiot badań, to jednak nie zaniechał tworzenia teorii ${ }^{1}$.

Radykalna zmiana rozpoczęła się w epoce Oświecenia. Wtedy to miano nauki (scientia) zaczęto nadawać badaniom przyrodniczym, a za prawdę zaczęto uważać to, co jest sprawdzalne eksperymentalnie. W konsekwencji filozofia i teologia utracily status nauki. Potem doszedł do tego marksizm, który postawił tezę, iż zadaniem nauki nie jest badanie świata, lecz jego zmienianie. Wypowiedź ta wprawdzie miała charakter polityczny, ale wpłynęła na sposób myślenia w ogóle.

Dotychczasową koncepcję widzenia i rozumienia zakwestionowali postmoderniści. Uznali oni też pierwsze zasady w filozofii, a dogmaty i tradycję w teologii za stereotypy zniewalające człowieka. Odrzucali oni istnienie odwiecznej prawdy i jej obiektywne poznawanie, a lansowali subiektywizm i doświadczenie, co prowadziło do relatywizmu w poznaniu i liberalizmu w postępowaniu. W konsekwencji widzenie oczu i wzrok rozumu przestały być potrzebne, bo niczemu nie służyły. Bóg przestał interesować badaczy, a kwestia zbawienia została zamknięta w doczesności, co rzecz jasna było sprzeczne z Biblią i z nauką Kościoła².

\section{Problem widzialności Zbawienia}

Popularnie zbawienie (salus) znaczy ratunek, ocalenie. Zwykle posługujemy się tym słowem wypadkach zagrażających życiu (na szosie, w wodzie, w kopalni itp.). Ratunek przychodzący w porę na ogół niesie ze sobą radość. Nie jest ona

\footnotetext{
1 J. Swastek, Erazm z Rotterdamu, [w:] Encyklopedia Katolicka, t. 4, Lublin 1985, kol. 1064.

2 J. Filipkowski, Postmodernizm, [w:] Encyklopedia Katolicka, t. 16, Lublin 2012, kol. 78.
} 
jednak w stanie zadowolić człowieka na całe jego życie. Zwykle też powszednieje i ulega zapomnieniu. „Nasze życie bowiem - pisze T. Merton - tak jako indywidualnych jak i członków rasy wiecznie niespokojnej i w trudzie zdobywającej sobie świat, wykazuje nam, że nasza egzystencja musi mieć jakiś sens”3.

Słowo „sens” jest nie mniej trudne niż „zbawienie”. Zwykle używamy go częściowo, na krótkim odcinku czasu. Uważamy np., że takie zajęcie ma sens, które pozwala widzieć jego skutek. Z tym często wiąże się zadowolenie, a ono nieraz przemija. Prawdziwy sens życia odnajduje człowiek wtedy, gdy rozciąga się on na całą jego egzystencję, gdy odpowiada na pytania: dlaczego żyję? Po co żyje? Jaki jest mój cel ostateczny? Co należy czynić, aby go osiągnąć?

Nie wszyscy ludzie chcą poszukiwać odpowiedzi na wymienione pytania. Wielu zadowala się doznaniami zmysłowymi. W korzystaniu z nich mają też różnorakie osiągnięcia, czasem artystyczne. Można przeto powiedzieć, że znajdują oni sens tego, co czynią. Ludziom prostym wystarcza to, by prowadzić spokojne życie i nie sprawiać kłopotu innym. Widzenie zmysłowe korzysta z pomocy wzroku umysłu, ale nie wymaga się od niego znajomości metafizyki lub teologii.

Od pytania jednak o sens życia nie można uciec w zetknięciu się ze śmiercią. Wtedy też natarczywie wraca problem zbawienia. Niektórzy, aby skrócić cierpienie, uciekają się do eutanazji. Jest to jednak ucieczka od pytania o sens życia lub poprzestanie na fałszywych podpowiedziach. Także przyjęcie stwierdzenia, że śmierć nie kończy życia, a tylko je zmienia, nie jest w stanie zadowolić ludzi, zwłaszcza tych, którzy umierają w cierpieniach i mękach. By to osiągnąć, widzenie Zbawienia, musi przekroczyć doczesność. Sposobność daje wzrok wiary.

Nie każda jednak wiara jest kluczem do nowej rzeczywistości. Zależy to bowiem od tego, komu się wierzy i jaką posiada się sprawdzalność wyznawanej wiary. W obrębie relacji międzyludzkich, wiara jest zawsze ryzykiem. Także liczenie na los nie zawsze przynosi to, czego się spodziewamy. Pomyłek w wierze nie da się zliczyć. Także w religijności często się mylono. Wiara, której wymaga Bóg Biblii od człowieka jest innego rodzaju.

Przede wszystkim jest ona darem od Boga, a nie wytworem człowieka. Wymaga ona od człowieka posłuszeństwa Bogu: im bardziej jest posłuszna, tym bardziej jest mocna. „Jeżeli nie uwierzycie, nie ostaniecie się” (Iz 7, 9); „Jeśli się nie nawrócicie, wszyscy tak samo zginiecie” (Łk 13, 5). W ten sposób „wiara jest poręką (substantia) tych dóbr, których się spodziewamy, dowodem (argumentum) tych rzeczywistości, których nie widzimy" (Hbr 11, 1). Na straży prawdziwej wiary stoi Kościól. Wierzymy w to, co Kościól podaje do wierzenia.

Jednakże wiara nie jest towarem wyciągniętym ze skarbca Kościoła. Wiara zawsze ma charakter personalny i Kościól pomaga ludziom pozostawać

T. Merton, Nikt nie jest samotna wyspa, Kraków b.r.w., s. 7. 
w osobowych związkach z Bogiem. Dzieje się to w konkretnym środowisku życia ludzi. Żyć wiarą trzeba tam, gdzie rozstrzygają się sprawy ludzkie i gdzie trzeba podejmować odpowiedź za słowa, gesty i czyny. Stąd też wierze towarzyszy widzialność w jej wyznawaniu i jej przekazywaniu.

Człowiek wierzący żyje na ziemi, a dąży do nieba. W stanie docelowym niebo jest niewidzialne na ziemi. „Ani oko nie widziało, ani ucho nie słyszało, ani serce człowieka nie zdołało pojąć, jak wielkie rzeczy przygotował Bóg tym, którzy Go miłują" (1 Kor 2, 9). Postrzegane natomiast jest jako obietnica dostępna dla umysłu i zmysłów. Z pomocą człowiekowi przychodzi symbol. Posługuje się on nim spontanicznie i programowo. Pozwala mu on przechodzić ze świata widzialnego do niewidzialnego. Należy on do jego natury i środowiska jego życia. W nim zakorzenia się język ludzki, sztuka i religia4.

Biblia pełna jest symboli, także Jezus Chrystus ciągle nimi się posługiwał. Używał podobieństw, opowiadań, porównań, obietnic i innych środków wyrazu. Odwoływał się do oczu i do serca, kazał wyciągać wnioski, pokazywał drogę, którą człowiek winien iść przez ziemię. A wszystko w relacji do celu ostatecznego. Zbawienie eschatologiczne w Jego nauczaniu było obecne jako obiecane i antycypowane zarazem.

\section{„Miejsce widzenia zajęło pouczanie”}

Antycypowanie Zbawienia jest procesem złożonym i skomplikowanym. Wprowadzono je wprawdzie w obszar widzenia, ale odwołano się do wzroku wiary. Bez niej oczy ludzkie byłyby bezsilne. Za swego życia na ziemi Jezus często nawiązywał do tego, co widzi się cielesnym wzrokiem. Po swoim jednak wstąpieniu do nieba „obłok zabrał Go sprzed oczu (Apostołów)” (Dz 1, 9). Nastąpiła radykalna zmiana sytuacji wierzących, którą św. Leon Wielki, papież (440-461) określa: „miejsce widzenia zajęło pouczanie” (Kazanie 2 na wniebowstapienie).

Leon Wielki był teologiem i humanistą. Szanowano go na Zachodzie i Wschodzie, a na Soborze Chalcedońskim (451 r.), po jego wykładzie o naro-

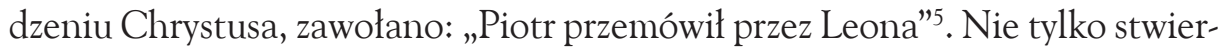
dził on, że po Wniebowstąpieniu Jezusa miejsce widzenia zajęło pouczanie, ale nadto wytłumaczył, jak to należy rozumieć i co to znaczy. Myśl jego jest zbieżna z nauczaniem wcześniejszego od niego ojca Kościoła św. Ambrożego (339-397), który był teologiem, politykiem i znawcą literatury antycznej ${ }^{6}$.

$4 \quad$ E. Cassirer, Esej o cztowieku. Esej do filozofii kultury, Warszawa 1977, s. 80. Zob. też S. K. Langer, Nowy sens filozofii, Warszawa 1974, s. 41-71.

5 G. Peters, Lire les Pères de l'Église: cours de patrologie, Paris 1981, s. 735-766.

6 Ibidem, s. 645-682. 
Święty Ambroży na temat widzenia zbawienia pisał w dziełkach $\mathrm{O}$ misteriach i O sakramentach. Święty Leon natomiast dodał do jego wywodu teologiczną podbudowę. W ten sposób obaj autorzy wzajemnie się uzupełniają.

Ich wykład można przedstawić następująco. Najpierw ważne jest stwierdzenie św. Leona, że wniebowstąpienie wnosi do zmartwychwstania Chrystusa nową jakość. W tym wydarzeniu bowiem „Chrystus wyniósł naszą słabą naturę ludzką na tron Ojca, ponad wszystkie wojska niebieskie, ponad chóry aniołów i wszystkie moce niebios"7. W nauczaniu często utożsamia się Zmartwychwstanie Jezusa z Jego Wniebowstąpieniem. Według ojców Kościoła wniebowstąpienie jest dopełnieniem Zmartwychwstania. $Z$ innego punktu widzenia pokazuje godność natury ludzkiej.

W Biblii te dwa wydarzenia oddzielone są od siebie czterdziestoma dniami. Jest to zabieg pedagogiczny. W wieczności bowiem nie ma następstwa dni. Wszystko jest teraz. Liczba dni została użyta po to, aby lepiej uzmysłowić to, co się stało po śmierci Jezusa na krzyżu. On zmartwychwstał, powstał do nowego życia jako prawdziwy człowiek, to jest w naturze ludzkiej. I tę naturę (naszą) wyniósł ponad chóry niebieskie, do tronu Ojca. Człowiek osiągnął cel ostateczny, a ludzkość otrzymała zapewnienie, że jest to możliwe.

Nauczanie św. Leona jest jeszcze bardziej szokujące, gdy stwierdza, że to, „co było widzialne w naszym Zbawicielu, zostało teraz zawarte w sakramentach" . Nie jest to bynajmniej zawężenie obszaru widzenia. Święty Leon wiedział, że Jezus po wstąpieniu do nieba nie opuścił ziemi, a tylko zmienił sposób bycia wśród ludzi. Wiele o tym pisano. Także Sobór Watykański II precyzyjnie się o tym wypowiedział ${ }^{9}$. Sobór uwzględnił stopniowanie obecności, które zależy od wiary człowieka i od woli samego Boga. Sakramenty w tej skali zajmują bardzo wysokie miejsce.

Sakramenty biorą początek w Chrystusie. On jest ich prasakramemtem. Także „Kościół jest w Chrystusie niejako sakramentem, czyli znakiem i narzędziem wewnętrznego zjednoczenia z Bogiem i jedności całego rodzaju ludzkiego"10. W Tradycji Kościoła sakramentalność uważano za sposób i metodę obecności Chrystusa na ziemi po Jego wstąpieniu do nieba. Wprawdzie w XII wieku dopiero Kościól orzekł, że sakramentów jest siedem, ale przez to nie zawęził dzieła Zbawienia, a tylko je uwyraźnił. Pokazując zwyczajną drogę Zbawienia, nie przekreślił dróg nadzwyczajnych. Bóg w rozdawnictwie łask przekracza

\footnotetext{
$7 \quad$ Leon Wielki, Mowa 74. O wniebowstapieniu 2, Poznań 1958, nr 1.

$8 \quad$ Ibidem, 2.

$9 \mathrm{KL}, 7$.

$10 \mathrm{KK}, 1$
} 
ludzkie ustalenia. Jego miłosierdzia nie powstrzymują grzechy ludzi. ( $\mathrm{Rz} 5$, 12-19). „Oddziaływanie łaski jest silniejsze niż oddziaływanie natury”"11.

\section{W liturgii sakramentów należy bardziej patrzeć na to, co niewidzialne niż widzialne}

Widzialność i niewidzialność dzieła zbawczego cechuje dialektyka. Wzajemnie się potrzebują, lecz do siebie się nie sprowadzają. „Czy wiara mogłaby nam przynieść usprawiedliwienie - uczy św. Leon - gdyby nasze zbawienie polegało tylko na ujrzeniu tego, co pozostaje w zasięgu naszego wzroku?"12. Człowiek pragnie widzieć to, do czego dąży jako do celu ostatecznego, ale nie może tego osiągnąć, bo „widzi niejasno jakby w zwierciadle” (1 Kor 13, 12). Rzeczywistość oglądana ukryta jest dla niego jakby za zasłoną. Nawet Apostołowie, wpatrujący się we wstępującego do nieba Chrystusa, musieli wrócić do dotychczasowych warunków życia.

Piękne są słowa św. Jana: „To wam oznajmiamy, co było od początku, cośmy usłyszeli o słowie życia, co ujrzeliśmy własnymi oczami, na co patrzyliśmy i czego dotykały nasze ręce, bo życie objawiło się. Myśmy je widzieli" (1 J 1, 1-2). Święty Jan odwołuje się do doświadczenia, od adresatów listu domaga się wzroku wiary.

Tego samego domagają się od swoich słuchaczy św. Ambroży i św. Leon Wielki, zwłaszcza przy sprawowaniu sakramentów. Ich wymóg jest szczególnego rodzaju, bo chcą, aby uczestnicy widzieli w sakramentach więcej niż widzą ich oczy. Widzialność sakramentów świętych jest dwuwarstwowa i to przyrodzona oraz nadprzyrodzona, sięga wyżej niż wzrok oczu i umysłu.

Symbolika sakramentów wznosi się wyżej niż oko ludzkie lub jego intelektualne rozumienie. Na ten szczyt wejść można tylko wiarą. W sakramentach świętych divina humanis iunguntur. Podobnie ma być w codziennym życiu.

W świecie symbol wskazuje i pokazuje, gdzie znajduje się rzeczywistość oznaczana. W sakramentach znak wskazuje, zawiera i urzeczywistnia to, na co wskazuje. $Z$ tego względu posiadają one szczególne znaczenie w porządku Zbawienia. Z tego też względu stawiają one szczególny wymóg tym, którzy je przyjmują.

Święty Ambroży uczył:

Co ujrzałeś? Wodę. Owszem lecz nie tylko. Zobaczyłeś jeszcze usługujący w tam lewitów i biskupa, które zadawał pytania i poświęcał. Apostoł nauczył cię jednak,

\footnotetext{
11 O sakramentach, 52.

12 Leon Wielki, Mowa 74, 3.
} 
że nie na to głównie trzeba patrzeć, co widzialne, lecz co niewidzialne, ponieważ rzeczy widzialne są doczesne, niewidzialny są wieczne $(2 \text { Kor } 4,15)^{13}$.

Wzrok wiary, umacniany sakramentami, powinien obejmować całe życie człowieka i prowadzić go do osiągnięcia celu ostatecznego. Wiary tej - uczy św. Leon - nie powinny „przerażać kajdany, więzienia, głód, ogień, wydanie na pożarcie dzikim zwierzętom, ani też żadne inne wymyślne katusze zadawane przez okrutnych prześladowców"14. Boga twarzą w twarz widzą zbawieni w niebie, oczami natomiast nie można dojść dalej niż do wiary. Jej wzrok jest wszystkim potrzebny.

Słowa kluczowe: Zbawienie, widzialność dzieła Zbawienia, liturgia, sakramenty, Ojcowie Kościoła.

\section{Bibliografia:}

1. Ambroise de Milan, Des sacrements des mystères, Paris 1980.

2. Ambroży, Wybór pism dogmatycznych, Poznań 1990.

3. Filipkowski J., Postmodernizm, [w:] Encyklopedia Katolicka, t. 16, Lublin 2012, kol. 73-75.

4. Cassirer E., Esej o człowieku. Esej do filozofii kultury, Warszawa 1977.

5. Langer S. K., Nowy sens filozofii, Warszawa 1974.

6. Leon Wielki, Mowy, Poznań 1958.

7. Merton T., Nikt nie jest samotna wyspa, Kraków b.r.w.

8. Peters G., Lire les Pères de l'Église: cours de patrologie, Paris 1981.

9. J. Swastek, Erazm z Rotterdamu, [w:] Encyklopedia Katolicka, t. 4, Lublin 1985.

13 O misteriach, 3, 8.

14 Leon Wielki, Mowa 74, 3. 